\title{
Crop-specific seasonal estimates of irrigation-water demand in South Asia
}

\author{
Hester Biemans $^{1}$, Christian Siderius ${ }^{1,2}$, Ashok Mishra ${ }^{3}$, and Bashir Ahmad ${ }^{4}$ \\ ${ }^{1}$ Alterra, Wageningen University and Research Centre, Wageningen, the Netherlands \\ ${ }^{2}$ Environmental Economics and Natural Resources Group, Wageningen University, Wageningen, the Netherlands \\ ${ }^{3}$ Agricultural and Food Engineering Department, IIT Kharagpur, Kharagpur, India \\ ${ }^{4}$ Pakistan Agricultural Research Council, Islamabad, Pakistan
}

Correspondence to: Hester Biemans (hester.biemans@wur.nl)

Received: 17 June 2015 - Published in Hydrol. Earth Syst. Sci. Discuss.: 12 August 2015

Revised: 5 March 2016 - Accepted: 8 March 2016 - Published: 17 May 2016

\begin{abstract}
Especially in the Himalayan headwaters of the main rivers in South Asia, shifts in runoff are expected as a result of a rapidly changing climate. In recent years, our insight into these shifts and their impact on water availability has increased. However, a similar detailed understanding of the seasonal pattern in water demand is surprisingly absent. This hampers a proper assessment of water stress and ways to cope and adapt. In this study, the seasonal pattern of irrigation-water demand resulting from the typical practice of multiple cropping in South Asia was accounted for by introducing double cropping with monsoon-dependent planting dates in a hydrology and vegetation model. Crop yields were calibrated to the latest state-level statistics of India, Pakistan, Bangladesh and Nepal. The improvements in seasonal land use and cropping periods lead to lower estimates of irrigation-water demand compared to previous model-based studies, despite the net irrigated area being higher. Crop irrigation-water demand differs sharply between seasons and regions; in Pakistan, winter (rabi) and monsoon summer (kharif) irrigation demands are almost equal, whereas in Bangladesh the rabi demand is $\sim 100$ times higher. Moreover, the relative importance of irrigation supply versus rain decreases sharply from west to east. Given the size and importance of South Asia improved regional estimates of food production and its irrigation-water demand will also affect global estimates. In models used for global water resources and food-security assessments, processes like multiple cropping and monsoon-dependent planting dates should not be ignored.
\end{abstract}

\section{Introduction}

As global demand for food increases, water resources - one of the main resources for producing food - are becoming increasingly stressed. South Asia, home to $\sim 25 \%$ of the world population, is often identified as one of the future waterstress hotspots (Kummu et al., 2014; Wada et al., 2011). Excess food production in recent years has obscured this bleak future; increases in both agricultural productivity and cropland extension have made the region food self-sufficient in its staple crops in recent decades. But the resources that supported this increase - surface- and groundwater extracted for irrigation, land converted into cropland, increased use of nutrients and pesticides - are not unlimited. Groundwater levels are already falling rapidly in large parts of South Asia due to overexploitation (Rodell et al., 2009; Tiwari et al., 2009) and surface-water irrigation is reaching its limits (Biemans, 2012), costly river interlinking schemes aside (Bagla, 2014; Gupta and Deshpande, 2004). In addition, higher temperatures and an expected higher variability in climate due to global warming further jeopardizes future food production in this region (Krishna Kumar et al., 2004; Mall et al., 2006; Moors et al., 2011).

In order to understand if, when and where water availability to sustain crop production becomes critical, a more thorough understanding of the potential mismatch between seasonal water availability and demand is required. In recent years, our insight into the seasonal pattern of water availability has increased due to a better understanding of fluctuations in monsoon onset (Goswami et al., 2010; Kajikawa et al., 2012; Ren and $\mathrm{Hu}, 2014$ ), and the variation in 
the active-break cycle of the monsoon, which governs intraseasonal droughts (Joseph and Sabin, 2008), both influenced by large-scale phenomena like El Niño (Joseph et al., 1994). Effort has also gone into quantifying the seasonal availability of snowmelt and glacier melt runoff on the regional scale (Bookhagen and Burbank, 2010; Siderius et al., 2013a), with intra-annual shifts in runoff expected in the future due to climate change (Immerzeel et al., 2013; Lutz et al., 2014; Mathison et al., 2015; Rees and Collins, 2006). When it comes to estimating water demand, however, a similar detailed understanding of the seasonal pattern is surprisingly absent.

Two essential and well-known agricultural characteristics that distinguish South Asia from most other large foodproducing regions in the world govern this water demand. First, South Asia's agriculture is characterized by a high degree of multiple cropping. A first crop during the monsoon season (kharif) is often succeeded by a second crop during the dry season (rabi) (Portmann et al., 2010). Planting dates for the kharif crop are determined primarily by the onset of the monsoon rather than by an accumulation of degree days. High maximum temperatures form a constraint for crop production during the rabi season, favouring planting as early as possible. Second, with rainfall highly concentrated during June-September and significant moisture deficits occurring during the other months of the year, crop production is to a very large extent supported by a combination of canal and groundwater irrigation, especially in the dry winter season (rabi) (GoI, 2012).

Many models that are used for global to regional water resources assessments still lack representation of multiple cropping (e.g. Arnold and Fohrer, 2005; Best et al., 2011; Gerten et al., 2004; Liang et al., 1994). Typically, a single cropping period per year is simulated with a degree-daybased or predefined single planting date (see, e.g., Elliott et al., 2014; Kummu et al., 2014). Exceptions are the model by Wada et al. (2011), who applied multiple cropping in their estimation of water stress, but in a simplified aggregated form without distinguishing between different crops and the models of Alcamo et al. (2003) and Hanasaki et al. (2008), who applied multiple-cropping seasons using optimized planting dates. However, Hanasaki et al. (2008) noted that their optimization mainly reacted to cold spells and was performed under rainfed conditions, which does not lead to optimal planting dates for the South Asia region. The study of Hoogeveen et al. (2015) accounted for multiple cropping by incorporating national level FAO cropping calenders, but only present total mean annual irrigation demands for South Asia (Table 1). Siebert and Döll (2010) also took multiple cropping into account by using MIRCA land use data (as in the present study; see Sect. 2.2) and cropping calenders (Portmann et al., 2010). They showed results for global seasonal irrigation demands, but not for South Asia specifically. As a result, crop-specific seasonal estimates of irrigation-water demand in South Asia are still lacking.

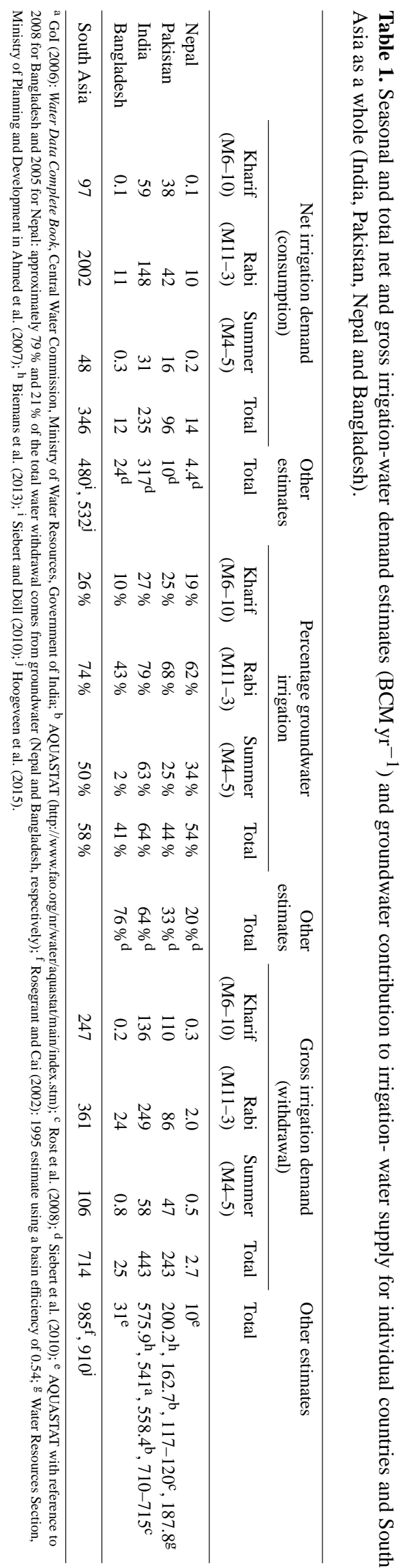

www.hydrol-earth-syst-sci.net/20/1971/2016/ 
In this paper, we aim to provide such spatially explicit, crop-specific seasonal estimates of water demand and crop production, using a revised version of the LundPotsdam-Jena managed Land (LPJmL) hydrology and vegetation model (Gerten et al., 2004), adjusted for the region. We distinguish two main South Asian cropping periods, kharif and rabi, and introduce zone-specific, monsoononset-determined planting dates for 12 major crop types, both rainfed and irrigated. We calibrate the improved model against the latest sub-national statistics on seasonal crop yields from four different countries - India, Pakistan, Nepal and Bangladesh - and explicitly evaluate the irrigation-water demand and crop production for the two cropping seasons.

\section{Methodology}

\subsection{LPJmL}

We used the LPJmL global hydrology and vegetation model for bio- and agro-spheres (Bondeau et al., 2007; Sitch et al., 2003), but developed a version that contains more spatial and temporal detail for South Asia. The LPJmL model has been widely applied to study the effects of climate change on water availability and requirements for food production at a global scale (Gerten et al., 2011; Falkenmark et al., 2009) and the potential of rainfed water-management options for raising global crop yields (Rost et al., 2009). For South Asia, the model has been applied to study the adaptation potential of increased dam capacity and improved irrigation efficiency in light of climate change (Biemans et al., 2013). LPJmL physically links the terrestrial hydrological cycle to the carbon cycle, making it a suitable tool for studying the relationship between water availability and crop production. The model includes algorithms to account for human influences on the hydrological cycle, e.g. irrigation extractions and supply (Rost et al., 2008). Production and water use for 12 different crops, both rainfed and irrigated are simulated. LPJmL is a gridbased model, run at a resolution of $0.5^{\circ}$, and at a daily time step.

Net irrigation-water demand (consumption) for irrigated crops is calculated daily in each grid cell as the minimum amount of additional water needed to fill the soil to field capacity and the amount needed to fulfil the atmospheric evaporative demand (Rost et al., 2008). Subsequently, the gross irrigation demand (withdrawal) accounts for application and conveyance losses, and is calculated by multiplying the net irrigation-water demand with a country-specific efficiency factor (Rohwer et al., 2007), which is different for surfacewater irrigation and groundwater irrigation (as in Biemans et al., 2013). Irrigation efficiency for canal water is estimated at $37.5 \%$ in India, Bangladesh, Nepal and $30 \%$ in Pakistan (Rohwer et al., 2007); efficiency of groundwater irrigation is estimated at $70 \%$ for all countries (following Gupta and Deshpande, 2004).
Surface water is defined as the water available in local rivers, lakes and reservoirs and is calculated by a daily routing algorithm (Biemans et al., 2009). Irrigation-water demand is assumed to be withdrawn from available surface water first. If surface water is unavailable, it is assumed to be withdrawn from groundwater (Rost et al., 2008).

Crop growth is simulated based on daily assimilation of carbon in four pools: leaves, stems, roots and harvestable storage organs. Carbon allocated to those pools depends on crop phenology and is adjusted in case of water stress on the plants. Crops are harvested when either maturity or the maximum number of growing days is reached (Bondeau et al., 2007; Fader et al., 2010).

To improve the understanding of spatial and temporal heterogeneity in irrigation-water demand and crop production in South Asia, we made some adjustments to the version of LPJmL that is used for global studies. First of all, we introduced the simulation of two cropping cycles per year by developing two different land use maps for kharif and rabi. Second, we applied zone-specific sowing dates related to monsoon patterns. Third, we accounted for regional differences in crop management by performing a calibration of crop yields at the subnational level. In the next three sections, those adjustments to LPJmL are explained in more detail.

In our experimental set-up, LPJmL is forced with daily precipitation, daily mean temperature, net longwave and downward shortwave radiation derived from the WFDEI data set (WATCH Forcing Data methodology applied to ERAInterim reanalysis data) (Weedon et al., 2014). Using this data set, all LPJmL simulations were done for the period 1979-2009 after a 1000 year spin-up period to bring carbon and water pools into equilibrium. The calibration and all analysis presented in this paper uses the simulation results of the period 2003-2008 for comparison with available statistics. Kharif and rabi irrigation-water demand and crop production are estimated by performing two simulations using different land use input and sowing-date input data sets. Those two runs are subsequently combined to attain the seasonal pattern for irrigation-water demand and crop production.

For comparison and to show model improvements, LPJmL is also run with the single cropping land use input as in previous model studies (Biemans et al., 2013) for which sowing dates are determined based on climate as in Waha et al. (2012).

\subsection{Development of land use maps for kharif and rabi seasons}

To derive land use input for two separate cropping seasons for South Asia, we used the MIRCA2000 database (MIRCA, version 1.1; Portmann et al., 2010) on a 5 min resolution. MIRCA is a global spatially explicit data set on irrigated and rainfed monthly crop areas for 26 crop classes around the year 2000. On an annual basis, MIRCA is consistent with 
other gridded data sets for total cropland extent (Ramankutty et al., 2008), total harvested area (Monfreda et al., 2008), and area equipped for irrigation (Siebert et al., 2007), but has more temporal detail. For India, MIRCA2000 includes subnational (i.e. state-level) information on the start and end of cropping periods. The data set explicitly includes multiple cropping.

Crop classes in MIRCA2000 were first aggregated to the crop classes available in the LPJmL model, which are fewer (12, irrigated and non-irrigated, plus one class with "other perennial crops", versus 26 in MIRCA) but include the most important food crops for South Asia (see Fig. 2 for distinguished crops). The exact period of monsoon (kharif) and dry season (rabi) cropping differs according to region. In India, kharif sowing is strongly related to the onset of the monsoon, whereas in large parts of Pakistan - where the monsoon is less pronounced - sowing can happen earlier or later because other factors like water availability for irrigation are more important. From the monthly MIRCA cropping calendars we decided to define the cropped area of the kharif season as the area under cultivation per crop as in September and that of rabi as the area per crop as in January. Perennial crops were only included in the kharif land use map.

Next, a few adjustments to the obtained data were made. First, MIRCA specifies three rotations of rice in northern India, two during summer and one during winter months. We merged the two summer rotations to the kharif rice area and allocated one to the rabi rice area, accepting a potential minor mismatch between data sets. Second, we corrected wheat and rice areas, both of which MIRCA equally divides over rabi and kharif. In reality, rice is mainly cropped during the kharif season and wheat is only cropped during the rabi (winter) season, when temperatures are lower and heat stress is avoided. We shifted all irrigated wheat to the rabi season and made compensations where possible by shifting an equal amount of irrigated rice area to the kharif season. Third, we shifted $45 \%$ of area cropped with pulses from the rabi to kharif season to comply with the latest agricultural statistics (GoI, 2012). In this way, consistency with other data sets was largely maintained (i.e. total cultivated area, cultivated area per crop, area irrigated), while at the same time a better match with crop phenology and regional agricultural practices was achieved.

Finally, we updated the area irrigated to the latest statistics. MIRCA represents land use and irrigated area for the period 1998-2002. Over the past 10 years, irrigated area has further increased in India alone from 76 to 86 million ha (gross irrigated area), to $44 \%$ of the total area. Statistics for India show (GoI, 2012) that the increase in irrigated area occurred for all crops. By shifting $10 \%$ of rainfed area to irrigated area, while keeping the overall cropped area the same, we achieved an increase in gross irrigated area. We assumed that the all-India trend is mirrored in the neighbouring counties. Cropped area was then aggregated to $0.5^{\circ}$ grids for both kharif and rabi, which formed the input into the LPJmL model. The resulting

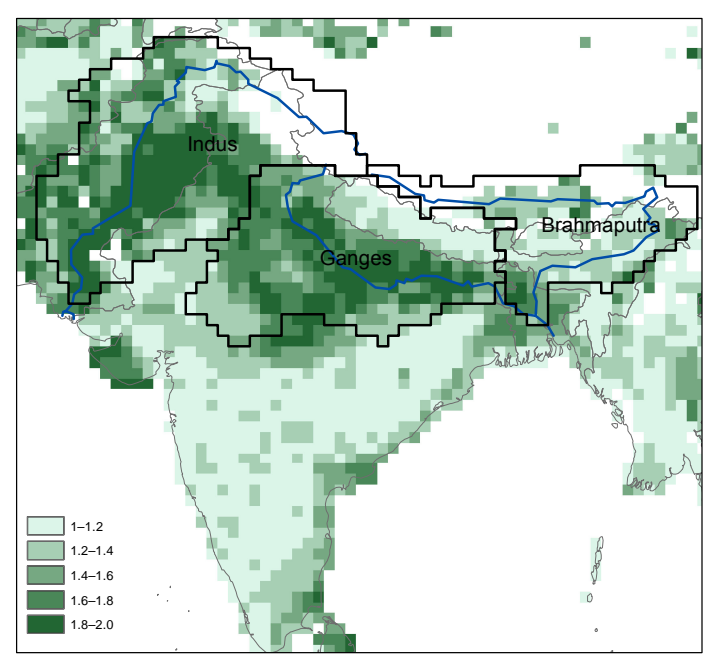

Figure 1. Cropping intensity in South Asia (land use data sets derived for this study based on MIRCA2000. Average cropping intensity is defined here as the total annual harvested area (kharif and rabi) divided by the maximum cropped area of the two cropping seasons. Study-basin delineations are indicated in black.

land use input is in good agreement with subnational statistics on cropping areas in kharif and rabi (see Supplement, Figs. S1-S6).

Figure 1 shows the cropping intensity in the study region according to this newly compiled data set, as well as the delineation of the river basins for which we will present our results. Figure 2 shows the total cropped area during the kharif and rabi seasons for all major crops in South Asia (India, Pakistan, Nepal and Bangladesh) according to the input data compiled here and compared to the agricultural statistics (GoI, 2014; Statistics, 2014).

\subsection{Adjusted planting dates for kharif and rabi crops}

Sowing dates for kharif crops are closely related to the onset of the monsoon as farmers start (trans)planting rice or other crops when the first rains have arrived. Normal onset dates of the monsoon over South Asia are determined by the India Meteorological Department, at 5- to 15-day intervals (IMD, 2015) (Fig. 3). The onset of the monsoon starts in Kerala in southern India around the first of June (Julian day 152) and arrives in western Pakistan around mid-July (Julian day 197). For the model simulations in this study, sowing dates for kharif crops were set to five days after the onset of the monsoon, because several days of rain are needed before a crop is (trans)planted (Fig. 3). Inter-annual variations in the onset of the monsoon were not taken into account in this study. The perennial crop sugarcane is assumed to be planted on this date as well.

In general, the kharif season ends by the end of October and the sowing of rabi crops starts early - from midNovember to early January, depending on local temperatures 


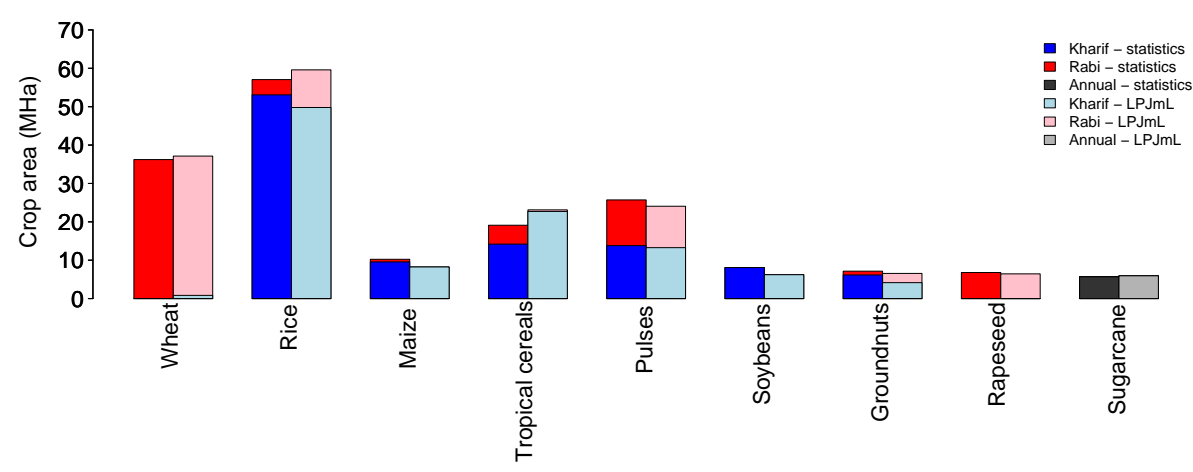

Figure 2. Total crop area in South Asia (India, Pakistan, Nepal and Bangladesh) for different crops in the two dominant growing seasons. National statistics (average of 2003-2008) versus LPJmL input data derived from MIRCA as described in Sect. 2.2. For the spatial distribution of crops between states and provinces of India and Pakistan, Nepal and Bangladesh, see Annex. Temperate and tropical roots and sunflower are not shown because they occupy relatively small areas; other perennial crops are not shown because there are no statistics available.
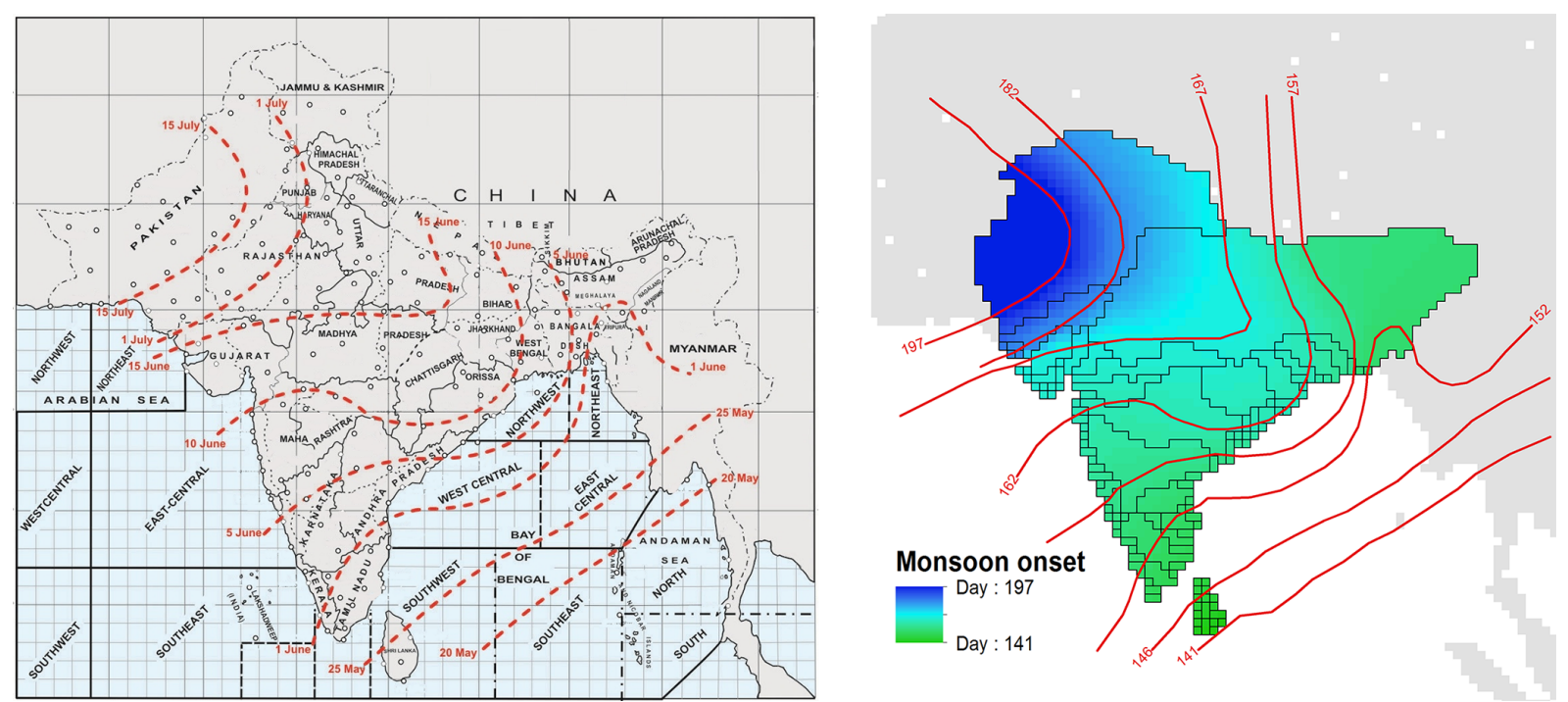

Figure 3. Normal dates for the onset of the south-west monsoon as presented by the Indian Meteorological Department (left panel) and interpolated over South Asia (right panel) derive input data for LPJmL, red numbers indicating Julian days, grey lines showing basin boundaries.

during winter and water availability in spring. As the exact date is difficult to determine, we set the first of November as the single sowing date for the rabi crops over the whole study area. Because the rabi crops are generally harvested by the end of March, the irrigation-water demand in the warm pre-monsoon summer months of April and May can almost entirely be attributed to perennial crops. In the analysis of seasonal irrigation demand, we therefore distinguish three seasons: kharif, from June until October; rabi, from November until March; and a dry "summer" season from April to May. This dry pre-monsoon summer season is sometimes also called Zaid season.

\subsection{Calibration of crop yields}

Crop yields in LPJmL are calibrated by varying management intensity, which is represented by three coupled parameters: maximum leaf area index, maximum harvest index, and a parameter that scales leaf-level biomass production to plot level (Fader et al., 2010). The three parameters are related to crop density, crop varieties and the occurrence of poor soils, pests and diseases, respectively. "Plot level" in this context means the total area of the crop within the grid cell: a plot shares the same climate, soil and land use. "Scale" means that a yield reduction has been applied to translate from biomass production of individual plants to plot level. Fader et al. (2010) explain this as follows: "The assumption is that intensively managed crop stands (LAImax $=7$ ) have little or no areas with reduced productivity due e.g. to poor soil conditions or pests and diseases $(\alpha-a=1.0)$, while such areas are more common in extensively managed crop stands (LAImax $=1$; $\alpha-a=0.4$ )" (for a detailed description of the calibration procedure, see Fader et al., 2010). 

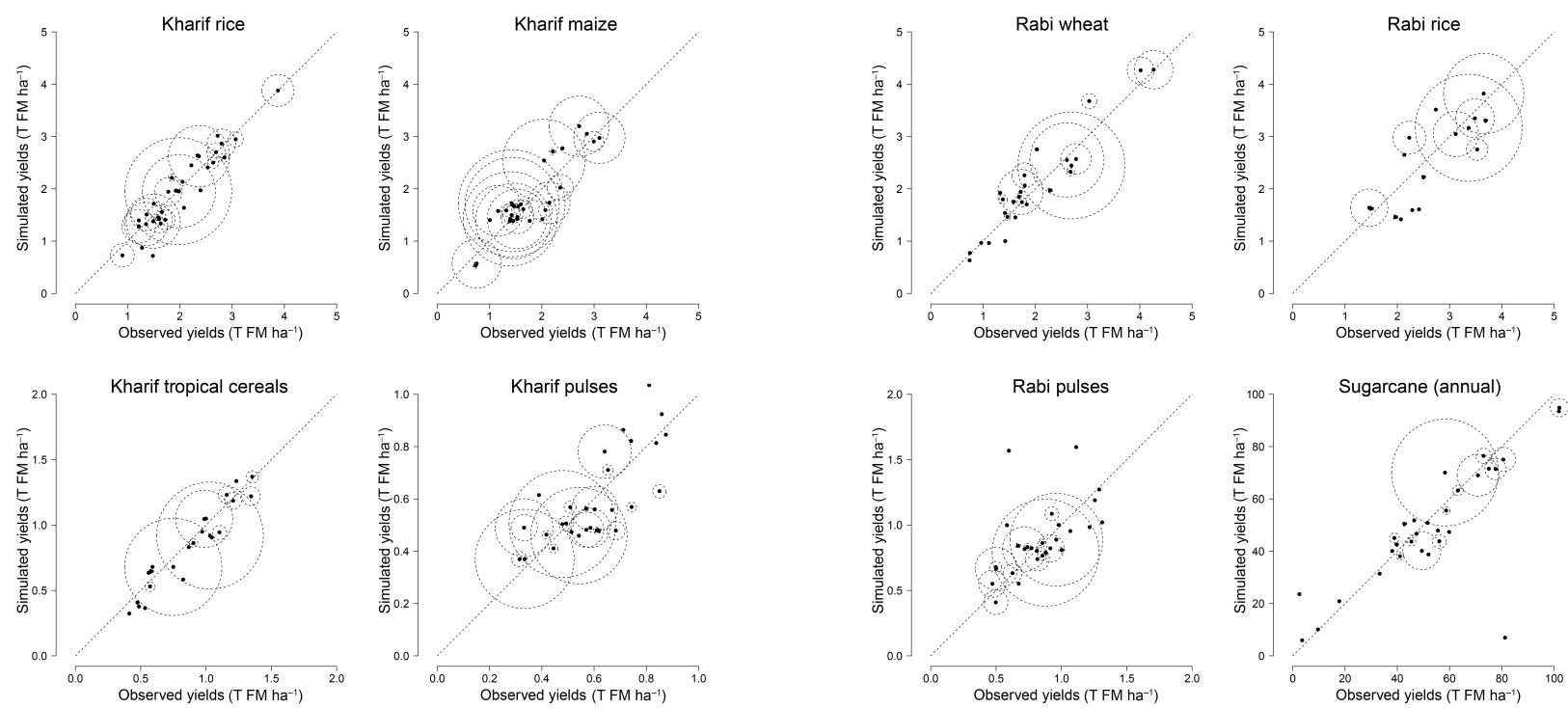

Figure 4. Observed vs. simulated (calibrated) crop yields for the most important crops in the different cropping seasons in tons of fresh matter per hectare $\left(T \mathrm{FM} \mathrm{ha}^{-1}\right)$. Each dot represents one state (India), province (Pakistan) or country (Nepal, Bangladesh). Size of the circle represents the relative area under that crop (for areas, see Figs. S1-S6).

The value of these management factors affects the estimated water demand, because a poorly developed crop with little leaf area will evaporate less and therefore demands less (irrigation) water and vice versa.

The calibration is performed for each crop individually, and management factors are usually determined at the country level in global applications of LPJmL. For this model version, we calibrated crop yields for kharif and rabi separately, as they are differentiated in the agricultural statistics. Moreover, we calibrated the management parameters at the sub-national level for India and Pakistan (state and province level, respectively) and at the national level for Nepal and Bangladesh. By calibrating at the sub-national level, existing spatial heterogeneity in management and crop yields between regions could be better represented. We used 5-year average yield statistics, for 2003-2004 till 2007-2008, the most recent period for which consistent records are available from different national agricultural statistics (India: GoI, 2012; Pakistan: http://www.pbs.gov.pk/ content/agricultural-statistics-pakistan-2010-11, last visited 1 July 2014; Bangladesh for the years from 2003-2004 till 2005-2006 form http://www.moa.gov.bd/statistics/statistics. htm\#3 and for 2007-2008 in the 2011 yearbook http://www. bbs.gov.bd/PageWebMenuContent.aspx?MenuKey=234;

Nepal; GoN, 2012). After calibration, the model is able to simulate the heterogeneity of (mean annual) yields between states and regions (illustrated in Fig. 4). Kharif rice and kharif maize crops show the highest variation between states and provinces. Overall, yields during the kharif season are lower than yields during the rabi season, when a higher percentage of the area cropped is irrigated, and temperatures are more favourable. Interannual variations in crop yields are shown and discussed by Siderius et al. (2016).

\section{Results}

\subsection{Seasonality in agricultural water demand}

Table 1 shows estimates of seasonal net (consumption) and gross (withdrawal from surface and groundwater) irrigationwater demand between the four countries. India and Pakistan have the largest water demand, both in terms of consumption and withdrawal. While Pakistan's net irrigation demand is almost equally divided over the kharif and rabi seasons, India's demand is skewed towards the rabi season; almost three-quarters of net irrigation demand in India occurs in this dry season (including pre-monsoon summer). This difference between kharif and rabi is less pronounced for gross irrigation demand, i.e. water withdrawals, which include application and conveyance losses. In the rabi season a much higher proportion of the irrigation water is supplied from groundwater (Table 1), which has a higher overall efficiency than surface-water irrigation from canals.

The seasonal distribution of irrigation-water demand is a result of rainfall patterns in the region. In Bangladesh and Nepal, monsoon rainfall is abundant for sustaining crop production during the kharif season and irrigation is therefore concentrated in the dry rabi season. Groundwater irrigation, modelled as the resultant of demand minus surface-water availability, provides most water resources 


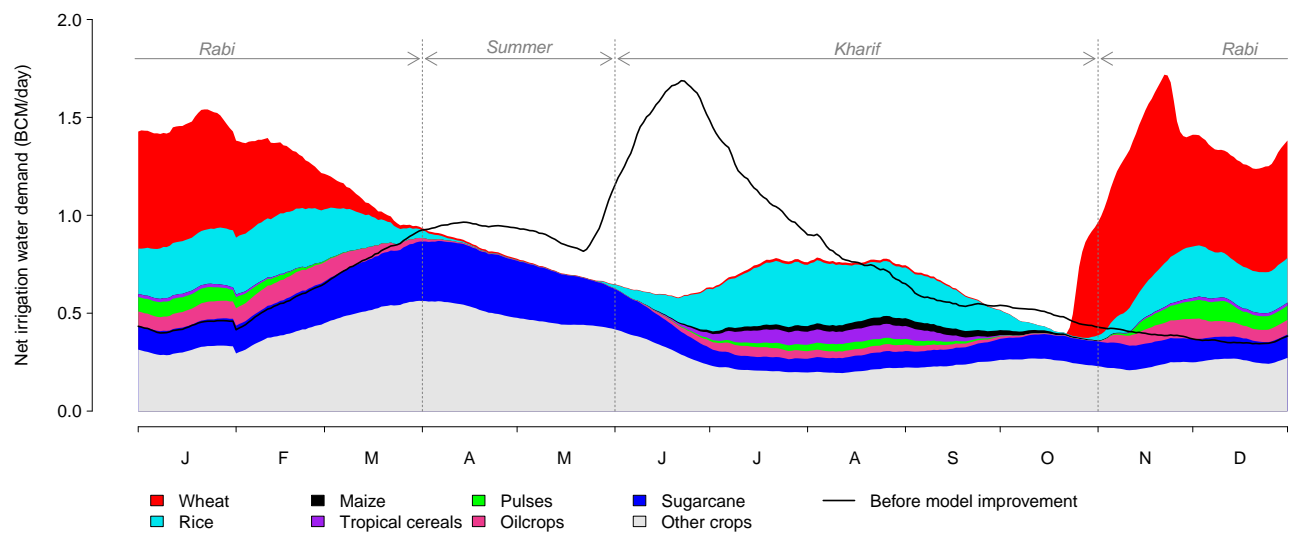

Figure 5. Mean annual cycle of net irrigation requirements for main agricultural crops in South Asia in BCM/day (30-day moving average). For comparison, the mean annual cycle of net irrigation requirements before model improvements (with single cropping season and climate driven sowing dates determination) is added in black.

during the rabi season in all countries, especially in India. In Pakistan, the Indus provides annually approximately $120 \mathrm{BCM} \mathrm{yr}^{-1}$ of utilizable runoff, of which approximately two-thirds is used during the kharif (Randhawa, 2002). Our estimate of mean annual groundwater withdrawal in Pakistan is at $60 \mathrm{BCM} \mathrm{yr}^{-1}$, of which three-quarters occurs during the rabi season and pre-monsoon summer. This is somewhat higher than previous estimates of groundwater withdrawal, which were in the range of at 47 to $55 \mathrm{BCM} \mathrm{yr}^{-1}$ (Ahmed et al., 2007; Qureshi et al., 2003; Wada et al., 2010) but still lower than the estimated total potential of $68 \mathrm{BCM} \mathrm{yr}^{-1}$ (Randhawa, 2002). For India, the exact distribution of surface-water and groundwater withdrawal between the kharif and rabi seasons is not well documented. Our model estimate of $217 \mathrm{BCM} \mathrm{yr}^{-1}$ of groundwater withdrawal, mainly occurring during the rabi season, is in agreement with earlier groundwater studies with estimates ranging from $190( \pm 37) \mathrm{BCM} \mathrm{yr}^{-1}$ by Wada et al. (2010) to 212.5 $\mathrm{BCM} \mathrm{yr}^{-1}$ (GoI, 2006).

Overall, our estimates of national total net and gross irrigation-water demand are in line with earlier studies and statistics, but at the lower end of the range for India. Accounting for monsoon-dependent planting dates, and thereby a more effective use of rainfall during the main kharif cropping season, reduced our estimate of total agricultural water demand compared to earlier regional studies, e.g. with the LPJmL model (Biemans et al., 2013). For Pakistan, our estimates are on the high side compared to other studies. Especially for the rabi season, we estimate a high additional demand from cash crops like cotton. This demand has to be met largely by groundwater abstractions, because runoff from the Indus and its tributaries is low during these months.

Evaluating the mean annual cycle of irrigation-water demand per crop reveals the reason behind seasonal differences in demand (Fig. 5). The single peak in net water demand for wheat during the rabi season stands out, while rice peaks in both rabi and kharif seasons. The moderating effect of monsoon rainfall during the kharif season is obvious, with net irrigation-water demand during the kharif season only accounting for about $30 \%$ of the annual net irrigation-water demand (Table 1). So while water-use efficiency improvements in rice receive much attention, paddy fields being the epitome of excessive water consumption, rice is actually not the most water-demanding crop in the region. Because rice is grown mainly during the kharif season in most states, its water demand is lower than for wheat and sugarcane, which are grown during the dry rabi season. Those crops therefore depend much more on groundwater availability (see also Table 1 and Fig. 6 for contribution of groundwater irrigation per cropping season). Additionally, sugarcane has an atypical demand in time, caused by its very long cultivation period of about 12 months; it requires large amounts of irrigation water in the hot dry months of March, April and May, a period when rainfall is scarce and most other fields are left fallow.

The mean annual cycle of irrigation demand as calculated with single cropping and sowing dates determined based on climate (before model improvement) are also shown in Fig. 5.

\subsection{Seasonal patterns of water demand for different basins}

As a result of varying climatological conditions and availability of spring and summer runoff from snow- and glacierfed rivers, cropping patterns and thereby seasonal water demand patterns differ greatly between the major river basins (Figs. 6 and 7). The Indus basin shows a relatively stable irrigation-water demand during the year, which is primarily fed by groundwater in winter and melt runoff in summer (Fig. 7). Downstream, monsoon rainfall contributes little to crop water needs. In the Ganges basin, a more seasonal pattern can be seen with demand for irrigation water being lower during the monsoon, when rainfall is sufficient over large 

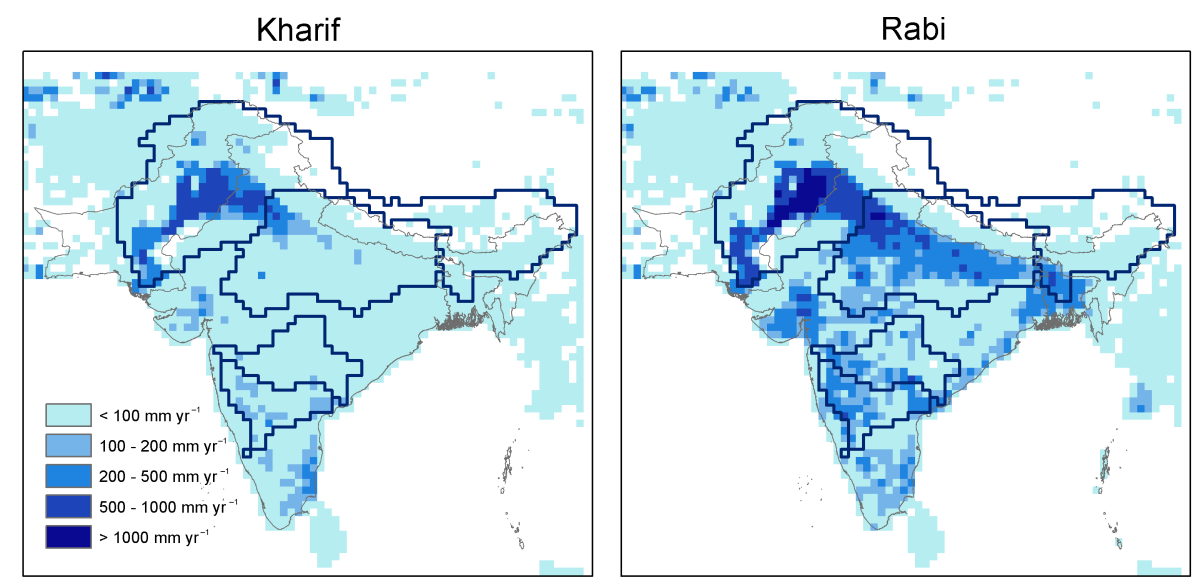

Figure 6. Gross irrigation-water demand for kharif (June to October) and rabi (November to March) cropping seasons, with selected river basins (Indus, Ganges, Brahmaputra).
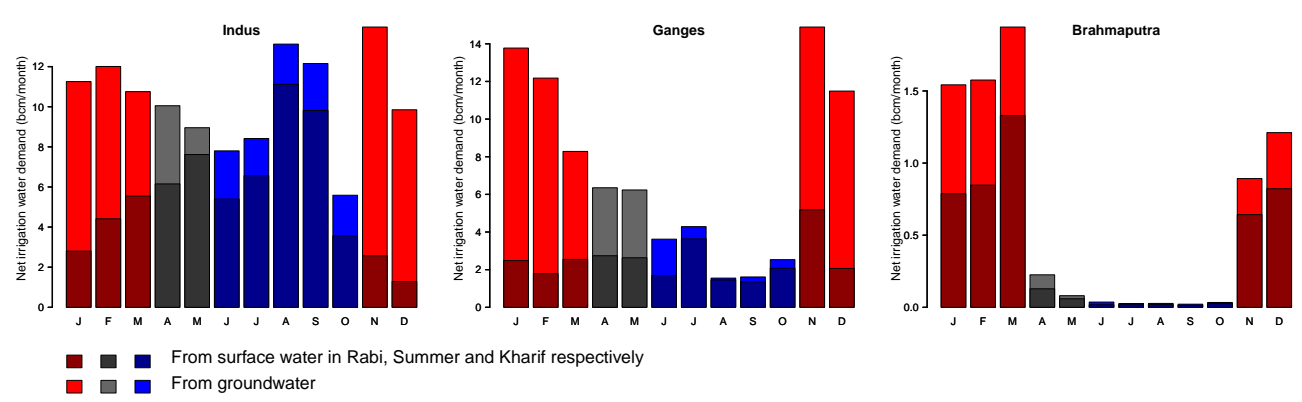

Figure 7. Monthly net irrigation-water demand for three river basins. Colours indicate the different seasons (red - kharif, grey - summer, blue - rabi) and the dark areas the source for supplying the irrigation water (dark - surface water, light - groundwater).

parts of the basin, and no additional irrigation is needed. The same pattern can be seen to be even stronger in the Brahmaputra basin.

\subsection{Food production in South Asia during the kharif- and rabi-cropping seasons}

Figure 8 shows the total seasonal production of only the five most important food crops (wheat, rice, maize, tropical cereals and pulses), both for the region as a whole as for the individual basins. The total area irrigated to grow these food crops is smaller in kharif than rabi (35 Mha vs. 46 Mha total for the four counties), but total (rainfed plus irrigated) area used to grow these food crops is much larger in kharif than rabi (95 Mha vs. $57 \mathrm{Mha}$ ). While the percentage of area under irrigation, productivity per hectare and sources of water used greatly differ between the kharif and rabi seasons, total regional food-crop production is remarkably similar in the two seasons. A lower cropped area during the rabi season is compensated for by higher yields. Of the total production of food crops in South Asia during the kharif season, $~ 50 \%$ is supported by irrigation (Fig. 8). In the rabi season up to $\sim 95 \%$ of food-crop production is supported by irrigation.
These estimates agree with the recent study of Smilovic et al. (2015), who focus on rice (kharif and rabi) and wheat (rabi) production in India only. They show that during kharif $68 \%$ of rice production is produced on irrigated lands, which is only $56 \%$ of the rice area sown. During rabi this percentage is much higher: $96 \%$ of the rice was irrigated (on $89 \%$ of the sown area) and $97 \%$ of the wheat production was irrigated (on $93 \%$ of the sown area) (Smilovic et al., 2015).

We also calculated the potential rainfed yield on those areas currently irrigated. Absence of irrigation would reduce the kharif food-crop production with $\sim 15 \%$ (dark blue bar in Fig. 8), against a reduction of almost $60 \%$ in rabi. This stresses the importance of sufficient irrigation-water supply for achieving food security in this region.

A closer look into the seasonal food production in the different river basins shows clear differences. The Indus and the Ganges have a much higher annual production of food crops than the Brahmaputra.

Rabi is the most important season for the production of food crops in the Indus. The same is true for the Ganges, although the production levels between the seasons are closer to each other. The rainfed production is much larger in the Ganges than in the Indus. In the Brahmaputra basin, the ma- 

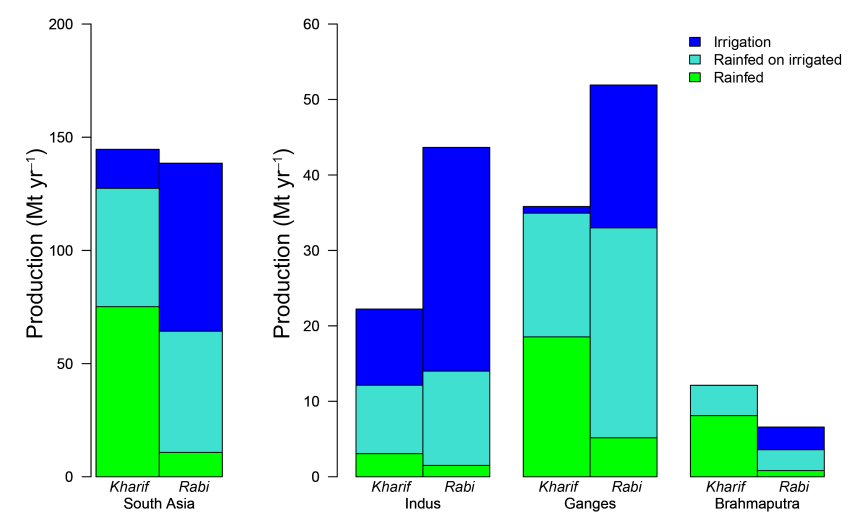

Figure 8. Mean annual seasonal irrigated (blue) and rainfed (green) production of food crops (sum of wheat, rice, maize, tropical cereals and pulses) in South Asia (Nepal, Pakistan, India and Bangladesh) and individual river basins. Light blue corresponds to potential rainfed production on irrigated land, i.e. dark blue corresponds to the increase in production due to irrigation.

jority of food-crop production takes place during the kharif season.

\section{Discussion}

The seasonal estimates presented here on food production and related irrigation-water demand in South Asia form a new baseline estimate of South Asian seasonal water demand and food-crop production, as they provide more spatial, temporal and crop-specific details than previous estimates.

Incorporating seasonal cropping patterns in more detail leads to improved estimation of the timing of water demand. Figure 5 shows that the simulated timing of water demand is very different compared to a simulation with old settings - thus single cropping season and calculated sowing dates. This difference shows the importance of including multiple cropping in the simulation of irrigation-water demand. Especially in this region with a very strong seasonal variability in both water availability and demand, an improved understanding of the (changes in) timing of both water availability and demand is essential to understand current and future water stressed regions. Therefore, the effect of multiple cropping on patterns of irrigation-water demand should not be neglected. We show that seasonal water demand is a factor of crop-specific seasonal consumption, availability of rainfall and different sources of water supply, i.e. groundwater or surface water, and the irrigation efficiencies connected to these sources. Despite these improvements, when modelling such large basins with complex hydrology and high diversity in agricultural and water-management practices, inevitably simplifications and local inaccuracies remain.

Our estimate of the net irrigation requirement (consumption) is influenced by the performed calibration and resulting management factors. Generally, regions with high manage- ment factors will show higher yields and higher transpiration, but lower soil evaporation. The effect of the calibration on our estimate of net irrigation requirements was tested by making two model runs: one with all management parameters set to the lowest possible value and one with all management parameters set to the highest possible values. This resulted in a net irrigation requirement for South Asia between 307 and $389 \mathrm{~km}^{3}$, a variation of about $10 \%$ compared to the here reported mean annual value of $346 \mathrm{~km}^{3}$.

Our estimate of gross irrigation demand, the water withdrawal, is strongly influenced by the water use efficiency value used, which is determined by a variety of factors like local irrigation practices, scale of analysis and source of water use. We used the most commonly reported values for the region, similar to other model-based studies in order to be able to compare results. Inclusion of regional, more application- and water-source-specific water use efficiency values in models would improve the estimation of gross water demand. Such detail is also necessary to gain better insight into the adaptation potential of different measures like drip irrigation and alternate wetting and drying.

More attention to seasonal cropping patterns and their water demand opens the scope for further model improvement. Double cropping was evaluated by combining two seasonal model runs, one for kharif and one for rabi. Use of residual soil moisture from one season to the other was not incorporated in this way, nor could the continued depletion of groundwater be accurately modelled. An integrated doublecropping routine, with proper calibrated crop-specific planting dates and yields, would provide such necessary analysis in a region where groundwater depletion is of serious concern.

Next, estimation of planting dates should be further improved, using detailed information on local agricultural practices and local water availability. Further, the sowing dates were kept constant during the whole simulation period and was based on average data of monsoon onset, although actual onsets vary year by year. In reality a farmer might decide year to year to sow earlier or later, which introduces an uncertainty in our calculations. Ample information is available in the irrigation domain but it will require a form of cooperation between experts at the local to national level and the water resources modelling community. Sharing of input data might reduce costs and time expenditure, will increase its uptake and improve overall quality of water resources assessments.

Finally, cropped area and sources of irrigation used are not constants or slowly evolving properties, but can be highly variable on inter-annual timescales in response to climate variability (Siderius et al., 2013b). These fluctuations were not assessed in the current study but are of high importance to individual farmers and the overall profitability of agriculture in regions with a variable climate. Combining an improved baseline of seasonal water demand with the inter-annual fluctuations in cropped area will lead to a more realistic assess- 
ment of both water demand and crop production, of high relevance in today's world with its volatile food commodity markets.

This paper highlights crop-specific periods of peak water demand that can form critical moments in agricultural production. Such better understanding of the size of water demand during critical moments, the crops that are responsible for this water demand, and its relative importance for food production is essential to guide sustainable development of climate adaptation measures. This analysis can support the selection of promising options to decrease irrigationwater demand. When combined with information on the (un)availability of surface water and the resulting pressure on groundwater resources (Fig. 7), it improves our understanding of the causes of water shortages and groundwater depletion. Finally, insight into the yield gap between rainfed and irrigated agriculture in specific regions, and between regions, can help target investments to improve irrigation practices or to increase productivity of rainfed agriculture.

\section{Conclusions}

Introducing seasonal crop rotation with monsoon-dependent planting dates in a global vegetation-hydrological model leads to better seasonal estimates of irrigation-water demand. Irrigation-water demand between the two main cropping seasons differs sharply both in terms of source and magnitude; gross irrigation demand during the rabi season is $\sim 30 \%$ higher than during the kharif season, the traditional cropping season, when monsoon rainfall reduces the amount of supplemental irrigation water needed. Our estimate of total annual water demand is lower than that of previous studies (Biemans et al., 2013), despite the net irrigated area being higher. Overall, gross annual irrigation demand is estimated at $714 \mathrm{BCM} \mathrm{yr}^{-1} ; 247 \mathrm{BCM} \mathrm{yr}^{-1}$ during the kharif monsoon season, $361 \mathrm{BCM} \mathrm{yr}^{-1}$ during rabi and $106 \mathrm{BCM} \mathrm{yr}^{-1}$ during the dry summer months of April and May.

Seasonal estimates of agricultural water demand better highlight crop-specific differences in peak water demand. Such increased temporal detail is needed for properly evaluating the impact of expected shifts in supply of water as a result of a rapidly changing climate, especially in the Himalayan headwaters of some of the main rivers in South Asia. With temperatures rising and total precipitation fairly constant, increased melt from glaciers combined with an early melt of the snow cover is expected to shift the peak in spring runoff to early in the season (Immerzeel et al., 2010; Lutz et al., 2014). Whether this shift will affect critical moments for irrigation or the ecosystem as a whole is to be assessed.

Our study has thereby more than regional relevance. Given the size and importance of South Asia, in terms of population and food production, improved regional estimates of production and its water demand will also affect global estimates.
In models used for global water resources and food-security assessments, processes like multiple cropping and monsoondependent planting dates should not be ignored.

\section{The Supplement related to this article is available online at doi:10.5194/hess-20-1971-2016-supplement.}

Acknowledgements. This work was carried out by the Himalayan Adaptation, Water and Resilience (HI-AWARE) consortium under the Collaborative Adaptation Research Initiative in Africa and Asia (CARIAA), with financial support from the UK Government's Department for International Development and the International Development Research Centre, Ottawa, Canada. We acknowledge the Potsdam Institute for Climate Impact Research for their support in using the LPJmL model and computational facilities.

Disclaimer. The views expressed in this work are those of the creators and do not necessarily represent those of the UK Government's Department for International Development, the International Development Research Centre, Canada or its Board of Governors.

Edited by: C. Stamm

\section{References}

Ahmed, A., Iftikhar, H., and Chaudhry, G.: Water resources and conservation strategy of Pakistan, Pakistan Dev. Rev., 997-1009, 2007.

Alcamo, J., Döll, P., Henrichs, T., Kaspar, F., Lehner, B., Rösch, T., and Siebert, S.: Development and testing of the WaterGAP 2 global model of water use and availability, Hydrolog. Sci. J., 48 317-337, 2008.

Arnold, J. G. and Fohrer, N.: SWAT2000: current capabilities and research opportunities in applied watershed modelling, Hydrol. Process., 19, 563-572, 2005.

Bagla, P.: India plans the grandest of canal networks, Science, 345, 128, doi:10.1126/science.345.6193.128, 2014.

Best, M. J., Pryor, M., Clark, D. B., Rooney, G. G., Essery, R. L. H., Ménard, C. B., Edwards, J. M., Hendry, M. A., Porson, A., Gedney, N., Mercado, L. M., Sitch, S., Blyth, E., Boucher, O., Cox, P. M., Grimmond, C. S. B., and Harding, R. J.: The Joint UK Land Environment Simulator (JULES), model description Part 1: Energy and water fluxes, Geosci. Model Dev., 4, 677-699, doi:10.5194/gmd-4-677-2011, 2011.

Biemans, H.: Water constraints on future food production, Wageningen UR, Wageningen, 168 pp., 2012.

Biemans, H., Hutjes, R. W. A., Kabat, P., Strengers, B. J., Gerten, D., and Rost, S.: Effects of precipitation uncertainty on discharge calculations for main river basins, J. Hydrometeorol., 10, 10111025, 2009.

Biemans, H., Speelman, L., Ludwig, F., Moors, E., Wiltshire, A., Kumar, P., Gerten, D., and Kabat, P.: Future water resources for food production in five South Asian river basins and potential for adaptation - A modeling study, Sci. Total Environ., 468, S117S131, 2013. 
Bondeau, A., Smith, P. C., Zaehle, S., Schaphoff, S., Lucht, W., Cramer, W., and Gerten, D.: Modelling the role of agriculture for the 20th century global terrestrial carbon balance, Global Change Biol., 13, 679-706, 2007.

Bookhagen, B. and Burbank, D. W.: Toward a complete Himalayan hydrological budget: Spatiotemporal distribution of snowmelt and rainfall and their impact on river discharge, J. Geophys. Res., 115, 1-25, 2010.

Elliott, J., Deryng, D., Müller, C., Frieler, K., Konzmann, M., Gerten, D., Glotter, M., Flörke, M., Wada, Y., Best, N., Eisner, S., Fekete, B. M., Folberth, C., Foster, I., Gosling, S. N., Haddeland, I., Khabarov, N., Ludwig, F., Masaki, Y., Olin, S., Rosenzweig, C., Ruane, A. C., Satoh, Y., Schmid, E., Stacke, T., Tang, Q., and Wisser, D.: Constraints and potentials of future irrigation water availability on agricultural production under climate change, $\mathrm{P}$. Natl. Acad. Sci., 111, 3239-3244, 2014.

Fader, M., Rost, S., Müller, C., Bondeau, A., and Gerten, D.: Virtual water content of temperate cereals and maize: Present and potential future patterns, J. Hydrol., 384, 218-231, 2010.

Falkenmark, M., Rockstrom, J., and Karlberg, L.: Present and future water requirements for feeding humanity, Food Secur., 1, 59-69, 2009.

Gerten, D., Schaphoff, S., Haberlandt, U., Lucht, W., and Sitch, S.: Terrestrial vegetation and water balance - hydrological evaluation of a dynamic global vegetation model, J. Hydrol., 286, 249270, 2004.

Gerten, D., Heinke, J., Hoff, H., Biemans, H., Fader, M., and Waha, K.: Global water availability and requirements for future food production, J. Hydrometeorol., 12, 885-899, doi:10.1175/2011jhm1328.1, 2011.

GoI: Dynamic groundwater resources of India (as of March, 2004), Central Ground Water Board, Ministry of Water Resources, Government of India, Faridabad, 2006.

GoI: Agricultural Statistics at a glance 2012, Government of India, Ministry of Agriculture, New Delhi, 2012.

GoI: http://eands.dacnet.nic.in/, last access: 22 July 2014, Directorate of economics and statistics, Department of Agriculture and Cooperation, Ministery of Agriculture, Government of India, 2014.

GoN: Statistical information on Nepalese Agriculture 2011/2012, Government of Nepal, Ministry of Agriculture, Kathmandu, 2012.

Goswami, B. N., Kulkarni, J. R., Mujumdar, V. R., and Chattopadhyay, R.: On factors responsible for recent secular trend in the onset phase of monsoon intraseasonal oscillations, Int. J. Climatol., 30, 2240-2246, 2010.

Gupta, S. K. and Deshpande, R. D.: Water for India in 2050: first-order assessment of available options, Current Science, 86, 1216-1224, 2004.

Hanasaki, N., Kanae, S., Oki, T., Masuda, K., Motoya, K., Shirakawa, N., Shen, Y., and Tanaka, K.: An integrated model for the assessment of global water resources - Part 2: Applications and assessments, Hydrol. Earth Syst. Sci., 12, 1027-1037, doi:10.5194/hess-12-1027-2008, 2008.

Hoogeveen, J., Faurès, J.-M., Peiser, L., Burke, J., and van de Giesen, N.: GlobWat - a global water balance model to assess water use in irrigated agriculture, Hydrol. Earth Syst. Sci., 19, 3829-3844, doi:10.5194/hess-19-3829-2015, 2015.
IMD: http://www.imd.gov.in/doc/wxfaq.pdf, last access: 30 September 2014, Indian Meteorological Department, Pune, 2015.

Immerzeel, W. W., van Beek, L. P. H., and Bierkens, M. F. P.: Climate Change Will Affect the Asian Water Towers, Science, 328, 1382-1385, 2010.

Immerzeel, W. W., Pellicciotti, F., and Bierkens, M. F. P.: Rising river flows throughout the twenty-first century in two Himalayan glacierized watersheds, Nat. Geosci., 6, 742-745, 2013.

Joseph, P. V. and Sabin, T. P.: An ocean-atmosphere interaction mechanism for the active break cycle of the Asian summer monsoon, Clim. Dynam., 30, 553-566, 2008.

Joseph, P. V., Eischeid, J. K., and Pyle, R. J.: Interannual variability of the onset of the Indian summer monsoon and its association with atmospheric features, El Nino, and sea surface temperature anomalies, J. Climate, 7, 81-105, 1994.

Kajikawa, Y., Yasunari, T., Yoshida, S., and Fujinami, H.: Advanced Asian summer monsoon onset in recent decades, Geophys. Res. Lett., 39, L03803, doi:10.1029/2011GL050540, 2012.

Krishna Kumar, K., Rupa Kumar, K., Ashrit, R. G., Deshpande, N. R., and Hansen, J. W.: Climate impacts on Indian agriculture, Int. J. Climatol., 24, 1375-1393, 2004.

Kummu, M., Gerten, D., Heinke, J., Konzmann, M., and Varis, O.: Climate-driven interannual variability of water scarcity in food production potential: a global analysis, Hydrol. Earth Syst. Sci., 18, 447-461, doi:10.5194/hess-18-447-2014, 2014.

Liang, X., Lettenmaier, D. P., Wood, E. F., and Burges, S. J.: A Simple hydrologically Based Model of Land Surface Water and Energy Fluxes for GSMs, J. Geophys. Res., 99, 415-428, 1994.

Lutz, A., Immerzeel, W., Shrestha, A., and Bierkens, M.: Consistent increase in High Asia's runoff due to increasing glacier melt and precipitation, Nat. Clim. Change, 4, 587-592, doi:10.1038/nclimate2237, 2014.

Mall, R., Singh, R., Gupta, A., Srinivasan, G., and Rathore, L.: Impact of Climate Change on Indian Agriculture: A Review, Climatic Change, 78, 445-478, 2006.

Mathison, C., Wiltshire, A. J., Falloon, P., and Challinor, A. J.: South Asia river-flow projections and their implications for water resources, Hydrol. Earth Syst. Sci., 19, 4783-4810, doi:10.5194/hess-19-4783-2015, 2015.

Monfreda, C., Ramankutty, N., and Foley, J. A.: Farming the planet: 2. Geographic distribution of crop areas, yields, physiological types, and net primary production in the year 2000, Global Biogeochem. Cy., 22, GB1022, doi:10.1029/2007GB002947, 2008.

Moors, E. J., Groot, A., Biemans, H., van Scheltinga, C. T., Siderius, C., Stoffel, M., Huggel, C., Wiltshire, A., Mathison, C., Ridley, J., Jacob, D., Kumar, P., Bhadwal, S., Gosain, A., and Collins, D. N.: Adaptation to changing water resources in the Ganges basin, northern India, Environ. Sci. Policy, 14, 758-769, 2011.

Portmann, F. T., Siebert, S., and Döll, P.: MIRCA2000 Global monthly irrigated and rainfed crop areas around the year 2000: A new high-resolution data set for agricultural and hydrological modeling, Global Biogeochem. Cy., 24, Gb1011, doi:10.1029/2008gb003435, 2010.

Qureshi, A. S., Shah, T., and Akhtar, M.: The groundwater economy of Pakistan, Working Paper 64, International Water Management Institute, Lahore, Pakistan, 31 pp., 2003.

Ramankutty, N., Evan, A. T., Monfreda, C., and Foley, J. A.: Farming the planet: 1. Geographic distribution of global agricultural 
lands in the year 2000, Global Biogeochem. Cy., 22, GB1003, doi:10.1029/2007gb002952, 2008 .

Randhawa, H. A.: Water development for irrigated agriculture in Pakistan: Past trends, returns and future requirements, Food and Agricultural Organization (FAO), FAO Corporate Document Repository, available at: www.fao.org/DOCREP/005/AC623E/ ac623e0i.htm (last access: 5 July 2014), 2002.

Rees, H. G. and Collins, D. N.: Regional differences in response of flow in glacier-fed Himalayan rivers to climatic warming, Hydrol. Process., 20, 2157-2169, 2006.

Ren, R. and Hu, J.: An emerging precursor signal in the stratosphere in recent decades for the Indian summer monsoon onset, Geophys. Res. Lett., 41, 7391-7396 doi:10.1002/2014GL061633, 2014.

Rodell, M., Velicogna, I., and Famiglietti, J. S.: Satellite-based estimates of groundwater depletion in India, Nature, 460, 999-1002, 2009.

Rohwer, J., Gerten, D., and Lucht, W.: Development of Functional Irrigation Types for Improved Global Crop Modelling, No. 104, Potsdam Institute for Climate Impact Research, Postdam, 98 pp., 2007.

Rosegrant, M. W. and Cai, X.: Global Water Demand and Supply Projections, Water Int., 27, 170-182, 2002.

Rost, S., Gerten, D., Bondeau, A., Lucht, W., Rohwer, J., and Schaphoff, S.: Agricultural green and blue water consumption and its influence on the global water system, Water Resour. Res., 44, W09405, doi:10.1029/2007WR006331, 2008.

Rost, S., Gerten, D., Hoff, H., Lucht, W., Falkenmark, M., and Rockström, J.: Global potential to increase crop production through water management in rainfed agriculture, Environ. Res. Lett., 4, 044002, doi:10.1088/1748-9326/4/4/044002, 2009.

Siderius, C., Biemans, H., Walsum, P. E. V. V., Ierland, E. V., Kabat, P., and Hellegers, P.: Snowmelt contributions to discharge of the Ganges, Sci. Total Environ., 468-469, S93-S101, 2013a.

Siderius, C., Hellegers, P. J. G. J., Mishra, A., van Ierland, E. C., and Kabat, P.: Sensitivity of the agroecosystem in the Ganges basin to inter-annual rainfall variability and associated changes in land use, Int. J. Climatol., 34, 3066-3077, doi:10.1002/joc.3894, 2013b.

Siderius, C., Biemans, H., van Walsum, P. E., van Ierland, E. C., Kabat, P., and Hellegers, P. J.: Flexible Strategies for Coping with Rainfall Variability: Seasonal Adjustments in Cropped Area in the Ganges Basin, Plos One, 11, e0149397, doi:10.1371/journal.pone.0149397, 2016.
Siebert, S. and Döll, P.: Quantifying blue and green virtual water contents in global crop production as well as potential production losses without irrigation, J. Hydrol., 384, 198-217, doi:10.1016/j.jhydrol.2009.07.031, 2010.

Siebert, S., Döll, P., Feick, S., Hoogeveen, J., and Frenken, K.: Global map of irrigation areas version 4.0.1, Johann Wolfgang Goethe University, Frankfurt am Main, Germany/Food and Agriculture Organization of the United Nations, Rome, Italy, 2007.

Siebert, S., Burke, J., Faures, J. M., Frenken, K., Hoogeveen, J., Döll, P., and Portmann, F. T.: Groundwater use for irrigation - a global inventory, Hydrol. Earth Syst. Sci., 14, 1863-1880, doi:10.5194/hess-14-1863-2010, 2010.

Sitch, S., Smith, B., Prentice, I. C., Arneth, A., Bondeau, A., Cramer, W., Kaplan, J. O., Levis, S., Lucht, W., Sykes, M. T., Thonicke, K., and Venevsky, S.: Evaluation of ecosystem dynamics, plant geography and terrestrial carbon cycling in the LPJ dynamic global vegetation model, Global Change Biol,, 9, 161185, 2003.

Smilovic, M., Gleeson, T., and Siebert, S.: The limits of increasing food production with irrigation in India, Food Secur., 7, 835-856, 2015.

Statistics: $\quad$ P.B.o., $\quad$ http://www.pbs.gov.pk/content/ agriculture-statistics-pakistan-2010-11, last access: 22 July 2014.

Tiwari, V. M., Wahr, J., and Swenson, S.: Dwindling groundwater resources in northern India, from satellite gravity observations, Geophys. Res. Lett., 36, L18401, doi:10.1029/2009GL039401, 2009.

Wada, Y., van Beek, L. P. H., van Kempen, C. M., Reckman, J. W. T. M., Vasak, S., and Bierkens, M. F. P.: Global depletion of groundwater resources, Geophys. Res. Lett., 37, L20402, doi:10.1029/2010GL044571, 2010.

Wada, Y., Van Beek, L. P. H., Viviroli, D., Dürr, H. H., Weingartner, R., and Bierkens, M. F. P.: Global monthly water stress: 2. Water demand and severity of water stress, Water Resour. Res., 47, doi:10.1029/2010WR009792, 2011.

Waha, K., van Bussel, L. G. J., Muller, C., and Bondeau, A.: Climate-driven simulation of global crop sowing dates, Global Ecol. Biogeogr., 21, 247-259, doi:10.1111/j.14668238.2011.00678.x, 2012.

Weedon, G. P., Balsamo, G., Bellouin, N., Gomes, S., Best, M. J., and Viterbo, P.: The WFDEI meteorological forcing data set: WATCH Forcing Data methodology applied to ERA-Interim reanalysis data, Water Resour. Res., 50, 7505-7514, 2014. 